\title{
Methodological Aspects of Extraction, Phytochemical Characterization and Molecular Docking Studies of Salix caprea L. Bark and Leaves
}

\author{
Emilia Gligorić, ${ }^{1}$ Ružica Igić, ${ }^{2}$ Ljiljana Suvajdžić, ${ }^{1}$ Branislava Teofilović, ${ }^{1}$ \\ Maja Turk-Sekulić, ${ }^{3}$ and Nevena Grujić-Letić ${ }^{1{ }^{*}}$ \\ ${ }^{1}$ University of Novi Sad, Faculty of Medicine, Department of Pharmacy, Hajduk Veljkova 3, 21000 Novi Sad, Serbia \\ ${ }^{2}$ University of Novi Sad, Faculty of Sciences, Department of Biology and Ecology, Trg Dositeja Obradovića 3, \\ Novi Sad, Serbia \\ ${ }^{3}$ University of Novi Sad, Faculty of Technical Sciences, Department of Environmental Engineering and Safety at Work, \\ Trg Dositeja Obradovića 6, Novi Sad, Serbia \\ *Corresponding author: E-mail: nevena.grujic-letic@mf.uns.ac.rs \\ Phone: +38121422760 Fax: +38121422760
}

Received: $10-30-2018$

\begin{abstract}
Contents of twelve selected bioactive substances and antioxidant potential of Salix caprea L. extracts were compared in its two vegetative organs (bark and leaves) and in terms of different ethanol/water mixtures used for extraction (30-70\% aq, ethanol) and extraction time (30 min; 24, 48 and $72 \mathrm{~h}$ ). The extracts were characterized by High Pressure Liquid Chromatography (HPLC), and total phenolics and flavonoids were determined spectrophotometrically. All secondary metabolites identified in Salix caprea L. extracts (gallic, chlorogenic and vanillic acid, epicatechin, rutin, quercetin and naringenin) were found more accumulated in bark. Salicin and $p$-hydroxybenzoic acid were detected in bark and ferulic, trans-cinnamic and $p$-coumaric acid in leaves extracts only. Rutin was most abundant bioactive compound both in bark $(1.71 \mathrm{~g} / 100 \mathrm{~g}$ of de) and leaves extracts $(0.434 \mathrm{~g} / 100 \mathrm{~g}$ of de). Bark extract with highest bioactive substances contents was obtained with $70 \%$ aq. ethanol as most suitable solvent during extraction time of $48 \mathrm{~h}$. Molecular docking showed salicin to have similar affinity toward COX-2 as acetylsalicylic acid, but lower toward COX-1.
\end{abstract}

Keywords: Extraction; HPLC; molecular docking; salicin; Salix caprea

\section{Introduction}

Willow bark (Salix spp., Salicaceae) is traditionally used herbal remedy due to its anti-inflammatory, analgesic and antipyretic properties. Salicin is usually described as the analgesic agent found in willow bark, responsible for its pharmacological effects. ${ }^{1-3}$ However, it was suggested that many of these effects cannot be explained by the presence of salicylic derivatives only and that other compounds such as polyphenols (flavonoids, flavan-3-ols) and simple phenols (phenolic acids) can contribute to the therapeutic effects of willow bark. ${ }^{4-8}$ On the other hand, leaves of many Salix species are mainly not studied and are considered as waste product after collection of bark.

Genus Salix includes about 350 different, mainly woody species. ${ }^{9}$ Salix caprea is a common species of wil- low native to Europe, Western and Central Asia and it is widely distributed in the flora of Serbia. It has been reported to exhibit strong antioxidant activity in many in vitro systems. ${ }^{10,11}$

Solvent extraction, i.e. solid-liquid extraction, is commonly used for the isolation of phenolic compounds from plant material. ${ }^{12}$ Extraction procedure and solvent selection are considered to be a critical point since they dictate the amount and nature of secondary metabolites transferred to extract. ${ }^{13}$ Some previous studies involving different plant material showed a great impact of solvent polarity and time of extraction on total extraction yield, antioxidant activity and bioactive compounds contents in final extracts. ${ }^{14-17}$ Ethanol and water mixtures are commonly used solvents for herbal extractions as they can dissolve a wide range of phenolics and are also acceptable for 
human consumption. ${ }^{18}$ By far mainly used solvents for the extraction of Salix caprea were $80 \%$ methanol for bark, $70 \%$ acetone for leaves, 95\% ethanol for flowers and 95\% acetone for wood and knots. ${ }^{12,19,20}$ There is no available data on testing the impact of different extraction conditions and solvent concentrations on total extraction yield, chemical composition and antioxidant activity of extracts obtained from bark and leaves of Salix caprea L. Thus, the objective of this study was to use different ethanol/water mixtures (30-70\% aq, ethanol) for extraction of two vegetative organs of Salix caprea L. during extraction time of 30 min; 24,48 and $72 \mathrm{~h}$ in order to gain extracts with the highest amount of target compounds.

COX- 1 and COX-2 are two isoforms of cyclooxygenase which has a role in conversion of arachidonic acid to prostaglandins that are involved in inflammatory processes in human body. Salicin is considered to be main compound found in willow responsible for its analgesic and anti-inflammatory properties. Salicylic acid, which is released in body from salicin, is considered to have similar affinity toward COX-2 as acetylsalicylic acid. ${ }^{21,22}$ Therefore, the secondary goal of this paper was to elucidate the interaction and binding affinity of salicin and COX-1 and COX-2 using molecular docking, an efficient tool to get an insight into ligand-receptor interactions. These molecular docking studies could be useful in better understanding of interactions between ligand and active sites of enzymes which is of great importance in aspect of designing a novel potent inhibitors.

\section{Experimental}

\section{1. Plant Material}

Bark and leaf of Salix caprea L., Salicaceae were collected from locality of Vlasina Lake, Serbia in June 2013. The plant material was air-dried and stored at room temperature. Dried willow bark and leaves were ground in a mill and particle size diameter $(\mathrm{d}=0.35 \mathrm{~mm})$ was determined by sieve set (Retsch GmbH and Co KG).

\section{2. Chemicals}

The following HPLC grade compounds were used as standards for analysis by HPLC-DAD: gallic acid (purity $\geq 97 \%$ ), chlorogenic acid (purity $\geq 95 \%$ ), ferulic acid (purity $\geq 99 \%$ ), rutin (purity $\geq 94 \%$ ), naringenin (purity $\geq 98 \%$ ), p-hydroxybenzoic acid (purity $\geq 99 \%$ ), vanillic acid (purity $\geq 97 \%$ ), trans-cinnamic acid (purity $\geq 99 \%$ ), epicatechin (purity $\geq 98 \%$ ) purchased from Sigma Aldrich; p-coumaric acid (purity $\geq 98 \%$ ) from Fluka; quercetin (purity $\geq 99 \%$ ) from Extrasynthese and salicin (purity $\geq 90 \%$ ) from Carl Roth. HPLC grade acetonitrile, methanol, o-phosphoric acid, tetrahydrofuran and acetic acid were obtained from J.T. Baker. Sodium carbonate and methanol (analytical grade) were purchased from
POCH, aluminium chloride from Sigma Aldrich. Folin-Ciocalteu (FC) reagent was obtained from Merck and 2,2-diphenyl-1-pycrylhydrazil (DPPH) from Alfa Aesar. Analytical grade EtOH was obtained from Zorka pharma. Distilled deionised water $\left(\mathrm{dd}_{2} \mathrm{O}\right)$ was used throughout the experiments.

\section{3. Extraction Procedure}

Ethanolic extracts were prepared as following: $0.5 \mathrm{~g}$ of plant material (bark/leaves) was extracted with $5 \mathrm{ml}$ of aqueous ethanol (30\%, $40 \%, 50 \%, 60 \% \mathrm{v} / \mathrm{v})$ for $30 \mathrm{~min}, 24$, 48 and 72 hours at room temperature $\left(25^{\circ} \mathrm{C}\right)$ and by method of maceration with $70 \%$ ethanol for 30 minutes to 72 hours at room temperature, according to the procedure given in EMA. ${ }^{23}$ After maceration, the extracts were filtered, evaporated to dryness and left in exicator for 24 hours. After measuring the weight of dry extract, the extraction yield was calculated.

\section{4. Chemical Characterization by High Performance Liquid Chromatography (HPLC)}

Chemical characterization of the obtained extracts and quantification of the selected compounds was carried out by applying HPLC method. ${ }^{24}$ Agilent HP 1100 HPLC-diode array detection (DAD) system equipped with an autosampler was used. The components were separated using reversed-phase Zorbax CB-C18 column $(4.6 \times 150$ $\mathrm{mm}, 5 \mu \mathrm{m}$ particle size) held at $25^{\circ} \mathrm{C}$. Solvent A was $0.1 \%$ aqueous $\mathrm{CH}_{3} \mathrm{COOH}$ and solvent $\mathrm{B}$ was $0.1 \% \mathrm{CH}_{3} \mathrm{COOH}$ in acetonitrile. The mobile phase used was delivered in gradient mode (3,25 min 10\% B; 8 min 12\% B; 15 min 25\% B; 15,8 min 30\% B; 25 min 90\% B; 25,4 min 100\% B), with flow rate of $1 \mathrm{~mL} / \mathrm{min}$. The HPLC mobile phase was prepared fresh daily and filtered through a $0.45 \mu \mathrm{m}$ nylon filter. The injection volume was $15 \mu \mathrm{L}$. For the quantification of the selected compounds, standards (gallic acid, chlorogenic acid, ferulic acid, rutin, naringenin, p-hydroxybenzoic acid, vannilic acid, trans-cinnamic acid, epicatechin, p-coumaric acid, quercetin) dissolved in methanol, were run under the same conditions. UV detection was set at $280 \mathrm{~nm}$.

Salicin was determined by a slightly modified HPLC method described earlier, ${ }^{25}$ using Zorbax CB-C18 column $(4.6 \times 150 \mathrm{~mm}, 5 \mu \mathrm{m}$ particle size). For quantification of salicin, the standard was dissolved in methanol and run under the same conditions.

Phenolic compounds were identified by comparing their retention time and UV/Vis spectra with those obtained from standard compounds. For quantitative analysis, a calibration curve for each standard was constructed: gallic acid $\left(\mathrm{y}=41245 \mathrm{x}-466.1, \mathrm{R}^{2}=0.998\right)$; chlorogenc acid $\left(y=13523 x-42.854, R^{2}=0.998\right)$, p-hydroxybenzoic acid $\left(y=22708 x+12.73, R^{2}=0.999\right) ;$ vanillic acid $(y=$ 
$\left.23028 \mathrm{x}+53.27, \mathrm{R}^{2}=1\right)$; epicatechin $\left(\mathrm{y}=6269 \mathrm{x}+23.72, \mathrm{R}^{2}\right.$ $=0.999) ; \mathrm{p}$-coumaric acid $\left(\mathrm{y}=67213 \mathrm{x}-75.38, \mathrm{R}^{2}=0.999\right)$; rutin $\left(\mathrm{y}=9921 \mathrm{x}-70.05, \mathrm{R}^{2}=0.999\right)$; ferulic acid $(\mathrm{y}=$ $\left.41992 \mathrm{x}-508.1, \mathrm{R}^{2}=0.999\right)$; trans-cinnamic acid ( $\mathrm{y}=$ $\left.11200 \mathrm{x}+69.55, \mathrm{R}^{2}=0.999\right)$; quercetin $(\mathrm{y}=19129 \mathrm{x}-103.3$, $\left.\mathrm{R}^{2}=0.999\right)$; naringenin $\left(\mathrm{y}=52671 \mathrm{x}-770.6, \mathrm{R}^{2}=0.999\right)$ and salicin $\left(\mathrm{y}=1927 \mathrm{x}-113.4, \mathrm{R}^{2}=0.995\right)$. The results were expressed in $\mathrm{g} / 100 \mathrm{~g}$ of dried extract.

\section{5. Antioxidant Activity - DPPH Assay}

The DPPH-assay was performed as previously described. ${ }^{26}$ Different volumes $(10-100 \mu \mathrm{l})$ of samples, dissolved in methanol, were mixed with $1 \mathrm{ml}$ of $90 \mu \mathrm{M} \mathrm{DPPH}$ solution and made up with $95 \%$ methanol to a final volume of $4 \mathrm{ml}$. After $1 \mathrm{~h}$ at room temperature, absorbance of the resulting solutions and the control (same chemicals without sample) were measured spectrophotometrically at $515 \mathrm{~nm}$ (Agilent $8453 \mathrm{UV}$-Visible Spectroscopy System). Methanol was used as a blank. For each sample, the experiment was performed in triplicate. RSC, expressed as a percentage, was calculated by the following equation:

$$
\text { RSC }=100 \times\left(A_{\text {blank }}-A_{\text {sample }}\right) / A_{\text {blank }}
$$

\section{6. Determination of Total Phenolics and Flavonoids Content}

Total phenolics and flavonoids content were determined spectrophotometrically by Agilent 8453 UV-Visible Spectroscopy System. The amount of total phenolic compounds in the extracts was assessed using the method described before. ${ }^{27}$ The concentration of total phenolics was expressed as mg of gallic acid equivalents per $\mathrm{g}$ of dried extract, using a standard curve of gallic acid $(y=0.2559 x+$ $0.3345)$. Measurement of the total flavonoid content in the obtained extracts was evaluated using the method based on formation of flavonoid-aluminium complex with the absorptivity maximum at $430 \mathrm{~nm} .^{28}$ The flavonoids content was expressed as $\mathrm{mg}$ of quercetin equivalents per $\mathrm{g}$ of dried extract, using a standard curve of quercetin $(\mathrm{y}=$ $0.0039 x+0.012)$. All measurements were performed in triplicate.

\section{7. Molecular Docking Studies}

Chemical structures of ligand molecules used in this research were taken from PubChem database (http://pubchem.ncbi.nlm.nih.gov/). Three dimensional crystallographic structures of proteins COX-1 in complex with flurbiprofen (1CQE) ${ }^{29}$ and COX-2 in complex with indomethacin $(4 \mathrm{COX})^{30}$ were retrieved from Protein Data Bank (PDB) (http://www.rcsb.org/). Ligands, chains B, C, $\mathrm{D}$ and molecules of water were erased, polar hydrogen atoms added and parcial atomic charge was calculated by
Gasteiger method, using AutoDock Tools. The dimension of the grid box was $60 \times 60 \times 60$ with distance of $0.375 \AA$ between points. Molecular docking was conducted using AutoDock 4.2.3. program package, by Lamarckian Genetic Algorithm, ${ }^{31}$ with standard docking procedure for rigid receptor and flexible ligand, with 25 independent runs per ligand. Other parameters were set to default. Conformations of docked structures with the lowest binding energy were considered as the most favorable docking pose. Discovery Studio Visualizer 4.5. was used to visualize the results and produce the figures.

\section{8. Statistical Analysis}

Statistical analyses were performed by SPSS, version 22. Results of extraction yield, total phenolics and flavonoids amount and antioxidant activity were analyzed using Student's t-test and one-way analysis of variance (ANOVA) to determine significant differences among samples with level of significance $\mathrm{p}<0.05$.

\section{Results and Discussion}

\section{1. Extraction Yield, Antioxidant Activity and Total Phenolics and Flavonoids}

Effects of operating conditions (extraction time and solvent polarity) on extraction yield of leaves and bark of Salix caprea L. are shown in Table 1.

Yield of Salix caprea L. leaves extracts ranged from 12.47 to $20.94 \mathrm{~g} / 100 \mathrm{~g}$ of drug and bark extracts from 9.49 to $16.77 \mathrm{~g} / 100 \mathrm{~g}$ of drug. Yield of dry extract of both leaves and bark, increased by increasing extraction time, due to longer contact between plant material and solvent. In case of leaves, differences in extraction length are significant only in $50 \%, 60 \%$ and $70 \%$ ethanol extracts, whereas in ethanolic bark extracts there is statistically significant difference between each time interval. Considering solvent polarity, by increasing ethanol concentration from $30 \%$ to $70 \%(\mathrm{v} / \mathrm{v})$, in case of bark, yield of dry extract increased, so the highest was achieved by $70 \%$ ethanol. In case of leaves, $40 \%$ ethanol as solvent was the most selective for obtaining the highest extraction yield. In terms of prolonged extraction time leading to increase of extraction yield, our results are in agreement with other similar researches. ${ }^{14,15}$ Also, the results obtained for S. caprea leavesare in accordance with the results of mate tea extraction from an earlier study, which revealed that the highest yield was achieved by using a more polar solvent, particularly $40 \%$ aqueous ethanol, ${ }^{16}$ as it was in case of S. caprea leaves as well.

The DPPH radical scavenging activity of the different extracts of bark and leaves of Salix caprea was assessed. Concentrations of extracts inhibiting $50 \%$ of DPPH radical $\left(\mathrm{IC}_{50}\right)$ are shown in Table 2. 
Table 1. Effects of extraction solvent on extraction yield (g dry extract / $100 \mathrm{~g}$ drug) of leaves and bark of Salix caprea

\begin{tabular}{|c|c|c|c|c|c|c|}
\hline Drug & $\begin{array}{l}\text { Extraction } \\
\text { time }\end{array}$ & 30\% EtOH & $40 \%$ EtOH & $\begin{array}{c}\text { Extraction type } \\
50 \% \mathrm{EtOH}\end{array}$ & $60 \%$ EtOH & 70\% EtOH \\
\hline Leaves & $\begin{array}{c}30 \mathrm{~min} \\
24 \mathrm{~h} \\
48 \mathrm{~h} \\
72 \mathrm{~h}\end{array}$ & $\begin{array}{l}17.14 \pm 1.49 \mathrm{a}^{\mathrm{a}} \\
19.12 \pm 0.28 \mathrm{a}^{\mathrm{a}} \\
19.43 \pm 0.84 \mathrm{a}^{\mathrm{a}} \\
20.55 \pm 2.09 \mathrm{a}^{\mathrm{a}}\end{array}$ & $\begin{array}{l}19.19 \pm 1.18 \mathrm{a}^{\mathrm{a}} \\
19.33 \pm 0.52 \mathrm{a}^{\mathrm{a}} \\
20.15 \pm 0.74 \mathrm{a}^{\mathrm{a}} \\
19.50 \pm 0.41_{\mathrm{a}^{a}}\end{array}$ & $\begin{array}{l}17.50 \pm 3.33 \mathrm{a}^{\mathrm{a}} \\
17.19 \pm 0.57 \mathrm{aab}^{\mathrm{ab}} \\
19.79 \pm 0.14 \mathrm{a}^{\mathrm{a}} \\
20.47 \pm 1.17 \mathrm{a}^{\mathrm{ac}}\end{array}$ & $\begin{array}{r}15.89 \pm 0.71 \mathrm{a}^{\mathrm{a}} \\
18.12 \pm 0.72 \mathrm{a}^{\mathrm{a}} \\
19 \pm 0.35 \mathrm{a}^{\mathrm{bc}} \\
19.89 \pm 0.48 \mathrm{a}^{\mathrm{c}}\end{array}$ & $\begin{array}{l}12.47 \pm 0.29 \mathrm{a}^{\mathrm{a}} \\
17.60 \pm 0.55 \mathrm{a}^{\mathrm{bc}} \\
19.23 \pm 0.52{ }_{\mathrm{a}}^{\mathrm{a}} \\
20.94 \pm 0.32{ }_{\mathrm{a}}{ }^{\mathrm{bd}}\end{array}$ \\
\hline Bark & $\begin{array}{l}30 \mathrm{~min} \\
24 \mathrm{~h} \\
48 \mathrm{~h} \\
72 \mathrm{~h}\end{array}$ & $\begin{array}{r}9.49 \pm 0.02 \mathrm{a}^{\mathrm{a}} \\
11.29 \pm 0.04 \mathrm{a}^{\mathrm{b}} \\
12.68 \pm 0.03 \mathrm{a}^{\mathrm{c}} \\
13.20 \pm 0.03 \mathrm{a}^{\mathrm{d}}\end{array}$ & $\begin{array}{l}10.22 \pm 0.02 \mathrm{a}^{\mathrm{a}} \\
12.72 \pm 0.03 \mathrm{a}^{\mathrm{b}} \\
13.30 \pm 0.03 \mathrm{a}^{\mathrm{c}} \\
14.23 \pm 0.03 \mathrm{a}^{\mathrm{d}}\end{array}$ & $\begin{array}{l}10.48 \pm 0.03 \mathrm{ac}^{\mathrm{a}} \\
11.76 \pm 0.04 \mathrm{ac}^{\mathrm{b}} \\
14.24 \pm 0.03 \mathrm{ac}^{\mathrm{c}} \\
15.15 \pm 0.02 \mathrm{ac}^{\mathrm{d}}\end{array}$ & $\begin{array}{l}13.02 \pm 0.03{ }_{b c d}{ }^{a} \\
14.01 \pm 0.03{ }_{b c d}{ }^{b} \\
14.72 \pm 0.03 b c d^{c}{ }^{c} \\
15.96 \pm 0.02 b_{b c d}{ }^{d}\end{array}$ & $\begin{array}{l}10.33 \pm 0.03 \mathrm{~cd}^{\mathrm{a}} \\
14.93 \pm 0.03 \mathrm{~cd}^{\mathrm{b}} \\
16.58 \pm 0.02 \mathrm{~cd}^{\mathrm{c}} \\
16.77 \pm 0.02 \mathrm{~cd}^{\mathrm{d}}\end{array}$ \\
\hline
\end{tabular}

Data are presented as mean value of triplicate measurements \pm standard deviation; Superscript letters within the same column indicate significant $(P<$ $0.05)$ differences of means within the extracting solvent; Subscript letters indicate significant $(P<0.05)$ differences of means between extraction types.

Table 2. Antioxidant activity of $S$. caprea leaves and bark extracts $[\mu \mathrm{g} / \mathrm{ml}]$

\begin{tabular}{|c|c|c|c|c|c|c|}
\hline Drug & $\begin{array}{l}\text { Extraction } \\
\text { time }\end{array}$ & $30 \%$ EtOH & $40 \%$ EtOH & $\begin{array}{c}\text { Extraction type } \\
50 \% \text { EtOH }\end{array}$ & $60 \%$ EtOH & 70\% EtOH \\
\hline Leaves & $\begin{array}{c}30 \mathrm{~min} \\
24 \mathrm{~h} \\
48 \mathrm{~h} \\
72 \mathrm{~h}\end{array}$ & $\begin{array}{r}26.82 \pm 0.2 \mathrm{a}^{\mathrm{a}} \\
16.04 \pm 0.27 \mathrm{a}^{\mathrm{b}} \\
7.48 \pm 0.27 \mathrm{a}^{\mathrm{c}} \\
60.15 \pm 0.15 \mathrm{a}^{\mathrm{d}}\end{array}$ & $\begin{array}{l}3.33 \pm 0.35_{\text {bcef }}{ }^{\mathrm{a}} \\
2.75 \pm 0.05_{\text {bcef }}{ }^{\mathrm{b}} \\
4.01 \pm 0.20_{\text {bcef }^{\mathrm{c}}} \\
4.45 \pm 0.05_{\text {bcef }}\end{array}$ & $\begin{array}{l}2.41 \pm 0.40_{\text {cdef }^{\mathrm{a}}} \\
6.02 \pm 0.08_{\mathrm{cdef}^{\mathrm{b}}} \\
3.80 \pm 0.05_{\mathrm{cdef}^{\mathrm{c}}} \\
2.79 \pm 0.26_{\text {cdef }}{ }^{\mathrm{d}}\end{array}$ & $\begin{array}{l}1.73 \pm 0.08 \mathrm{de}^{\mathrm{a}} \\
2.05 \pm 0.06_{\mathrm{de}}^{\mathrm{b}} \\
2.86 \pm 0.15 \mathrm{de}^{\mathrm{c}} \\
4.26 \pm 0.04 \mathrm{de}^{\mathrm{d}}\end{array}$ & $\begin{array}{l}1.57 \pm 0.04 \mathrm{e}^{\mathrm{a}} \\
3.72 \pm 0.08 \mathrm{e}^{\mathrm{b}} \\
3.42 \pm 0.18 \mathrm{e}^{\mathrm{c}} \\
4.24 \pm 0.05 \mathrm{e}^{\mathrm{d}}\end{array}$ \\
\hline Bark & $\begin{array}{c}30 \mathrm{~min} \\
24 \mathrm{~h} \\
48 \mathrm{~h} \\
72 \mathrm{~h}\end{array}$ & $\begin{array}{l}1.07 \pm 0.04{ }_{a f}{ }^{a} \\
3.03 \pm 0.08{ }_{a f}{ }^{b} \\
2.55 \pm 0.05{ }_{a f}{ }^{c} \\
3.34 \pm 0.06{ }_{a f}{ }^{d}\end{array}$ & $\begin{array}{l}1.35 \pm 0.03 \mathrm{acf}^{\mathrm{a}} \\
1.97 \pm 0.02 \mathrm{acf}^{\mathrm{b}} \\
2.49 \pm 0.04 \mathrm{acf}^{\mathrm{c}} \\
2.87 \pm 0.02 \mathrm{acf}^{\mathrm{d}}\end{array}$ & $\begin{array}{l}0.99 \pm 0.01 \text { bcde }{ }^{a} \\
1.80 \pm 0.03{ }_{b c d e}{ }^{b} \\
1.68 \pm 0.04{ }_{b c d e}{ }^{c} \\
1.31 \pm 0.01{ }_{b c d e}{ }^{d}\end{array}$ & $\begin{array}{l}1.33 \pm 0.01 \mathrm{~cd}^{\mathrm{a}} \\
2.59 \pm 0.03 \mathrm{~cd}^{\mathrm{b}} \\
1.61 \pm 0.06_{\mathrm{cd}}{ }^{\mathrm{c}} \\
1.21 \pm 0.01 \mathrm{~cd}^{\mathrm{d}}\end{array}$ & $\begin{array}{l}0.99 \pm 0.02 \mathrm{de}^{\mathrm{a}} \\
1.41 \pm 0.02 \mathrm{de}^{\mathrm{b}} \\
1.60 \pm 0.06 \mathrm{de}^{\mathrm{c}} \\
1.58 \pm 0.01 \mathrm{de}^{\mathrm{c}}\end{array}$ \\
\hline
\end{tabular}

Data are presented as mean value of triplicate measurements \pm standard deviation; Superscript letters within the same column indicate significant $(P<$ $0.05)$ differences of means within the extracting solvent; Subscript letters indicate significant $(P<0.05)$ differences of means between extraction types.

Lower $\mathrm{IC}_{50}$ values indicate higher antioxidant activity. $\mathrm{IC}_{50}$ values of bark extracts ranged from 0.99 to $3.34 \mu \mathrm{g} /$ $\mathrm{ml}$ indicating strong antioxidant activity. Increasing ethanol concentration from $30 \%$ to $70 \%$, antioxidant activity of bark extracts increased, whereas increased extraction time led to decrease of antioxidant activity. This could be explained by the fact that longer extraction time might increase the oxidation of phenolic compounds contributing to lower DPPH radical scavenging activity. ${ }^{32}$ The highest antioxidant activity of bark extracts was observed for $50 \%$ and $70 \%$ ethanol extracts after 30 min of maceration. Compared to results of antioxidant activity of Salix aegyptiaca ethanol bark extracts $(19 \pm 3 \mu \mathrm{g} / \mathrm{ml}),{ }^{33}$ our results indicate higher antioxidant activity. $\mathrm{IC}_{50}$ values of leaves extracts were in range of 1.57 to $60.15 \mu \mathrm{g} / \mathrm{ml}$, also indicating high antioxidant activity. Among leaves extracts the highest antioxidant activity was observed for $70 \%$ ethanol extract obtained after 30 min of maceration. Comparing the results of bark and leaves extracts, it can be noticed that bark extracts possess higher antioxidant activity. Compared to Salix caprea ethanol flower extract, where $\mathrm{IC}_{50}$ value was $75 \mu \mathrm{g} /$ $\mathrm{ml},{ }^{12}$ extracts of both bark and leaves exhibited stronger antioxidant activity, indicating that antioxidant potential could depend on the selected plant material.
The total phenolics content in the obtained extracts of bark and leaves of Salix caprea L. are presented in Table 3.

The amount of total phenolics in the investigated extracts ranged from 16.44 to $68.37 \mathrm{mg} \mathrm{GAE} / \mathrm{g}$ de and from 4.14 to $26.16 \mathrm{mg} \mathrm{GAE} / \mathrm{g}$ de in bark and leaves, respectively. Increasing ethanol concentration from $30 \%$ to $70 \%$, the amount of total phenolics increased for both bark and leaves extracts and the highest amount of phenolic compounds was observed in $70 \%$ ethanol extracts. The obtained results for bark extracts are lower than results from a study (75.5 $\pm 0.1 \mathrm{mg} \mathrm{GAE} / \mathrm{g}$ de) where Salix caprea bark was extracted by $80 \%$ aqueous methanol using Ultra Turrax. ${ }^{19}$ However, results obtained for most $70 \%$ ethanol leaves extracts in our study are higher than results of total phenolics in Salix caprea leaves extracts $(37.6 \pm 0.1 \mathrm{mg}$ $\mathrm{GAE} / \mathrm{g}$ de), where extraction was carried out by $70 \%$ aqueous acetone using magnetic mixer. ${ }^{19}$ Total phenolics content in $70 \%$ ethanol extracts of leaves is significantly higher than the amount of phenolics obtained by extraction with other concentrations of ethanol. There is a statistically significant difference between total phenolics content in bark and leaves extracts. The highest amount of phenolics in bark was achieved by extraction with $70 \%$ ethanol. 
Table 3. Total phenolics content of S.caprea leaves and bark extracts [mg of gallic acid equivalents per g of dried extract]

\begin{tabular}{|c|c|c|c|c|c|c|}
\hline Drug & $\begin{array}{l}\text { Extraction } \\
\text { time }\end{array}$ & $30 \%$ EtOH & $40 \%$ EtOH & $\begin{array}{c}\text { Extraction type } \\
50 \% \text { EtOH }\end{array}$ & $60 \% \mathrm{EtOH}$ & 70\% EtOH \\
\hline Leaves & $\begin{array}{c}30 \mathrm{~min} \\
24 \mathrm{~h} \\
48 \mathrm{~h} \\
72 \mathrm{~h}\end{array}$ & $\begin{array}{r}21.20 \pm 0.07 \mathrm{ad}^{\mathrm{a}} \\
8.22 \pm 0.26 \mathrm{ad}^{\mathrm{b}} \\
11.38 \pm 0.05 \mathrm{ad}^{\mathrm{c}} \\
12.09 \pm 0.08 \mathrm{ad}^{\mathrm{d}}\end{array}$ & $\begin{array}{r}22.92 \pm 0.13 \mathrm{abd}^{\mathrm{a}} \\
14.24 \pm 0.15_{\mathrm{abd}^{\mathrm{b}}} \\
5.84 \pm 0.04 \mathrm{abd}^{\mathrm{c}} \\
23.44 \pm 0.02 \mathrm{abd}^{\mathrm{d}}\end{array}$ & $\begin{array}{r}23.19 \pm 0.12 \mathrm{abd}^{\mathrm{a}} \\
20.69 \pm 0.12 \mathrm{abd}^{\mathrm{b}} \\
4.14 \pm 0.08 \mathrm{abd}^{\mathrm{c}} \\
18.82 \pm 0.07 \mathrm{abd}^{\mathrm{d}}\end{array}$ & $\begin{array}{l}17.56 \pm 0.24_{b c d}{ }^{a} \\
30.11 \pm 0.12_{b c d}^{b} \\
26.16 \pm 0.08_{b c d}{ }^{c} \\
22.62 \pm 0.04{ }_{b c d}{ }^{d}\end{array}$ & $\begin{array}{l}25.52 \pm 0.04{ }^{a} \\
33.98 \pm 0.02{ }^{b} \\
45.37 \pm 0.28_{c}{ }^{c} \\
41.14 \pm 0.02{ }^{d}\end{array}$ \\
\hline Bark & $\begin{array}{c}30 \mathrm{~min} \\
24 \mathrm{~h} \\
48 \mathrm{~h} \\
72 \mathrm{~h}\end{array}$ & $\begin{array}{l}51.12 \pm 0.31_{\mathrm{a}}^{\mathrm{a}} \\
17.31 \pm 0.09_{\mathrm{a}}^{\mathrm{b}} \\
20.16 \pm 0.17_{\mathrm{a}}^{\mathrm{c}} \\
23.76 \pm 0.22_{\mathrm{a}}^{\mathrm{d}}\end{array}$ & $\begin{array}{l}56.12 \pm 0.23_{a c}{ }^{a} \\
16.44 \pm 0.21_{a c}{ }^{b} \\
25.42 \pm 0.16_{a c}{ }^{c} \\
27.58 \pm 0.12_{a c}{ }^{d}\end{array}$ & $\begin{aligned} 48.89 & \pm 0.18^{a}{ }^{a} \\
45.82 & \pm 0.16^{b} \\
29 & \pm 0.18^{{ }^{c}} \\
26.84 & \pm 0.12^{\mathrm{a}}{ }^{\mathrm{d}}\end{aligned}$ & $\begin{array}{l}52.36 \pm 0.12_{\mathrm{ac}}{ }^{\mathrm{a}} \\
25.63 \pm 0.18_{\mathrm{ac}}{ }^{\mathrm{b}} \\
38.16 \pm 0.11_{\mathrm{ac}}{ }^{\mathrm{c}} \\
42.65 \pm 0.02_{\mathrm{ac}}{ }^{2}\end{array}$ & $\begin{array}{l}42.68 \pm 0.23_{b c}{ }^{a} \\
64.88 \pm 0.11_{b c}{ }^{b} \\
68.37 \pm 0.08_{b c}{ }^{c} \\
55.71 \pm 0.04_{b c}{ }^{d}\end{array}$ \\
\hline
\end{tabular}

Data are presented as mean value of triplicate measurements \pm standard deviation; Superscript letters within the same column indicate significant $(P<$ $0.05)$ differences of means within the extracting solvent; Subscript letters indicate significant $(P<0.05)$ differences of means between extraction types.

Total flavonoids content in the investigated bark and leaves extracts is shown in Table 4.

Increasing ethanol concentration led to the increase of total flavonoids of both bark and leaves extracts, so the highest amount of flavonoids was obtained by maceration with $70 \%$ ethanol. The amount of total flavonoids in bark extracts is significantly higher than in leaves extracts of $S$. caprea. The great impact of solvent polarity and extraction time on total flavonoid content found in this research is in agreement with other studies. ${ }^{15,16}$

\section{2. Chemical Composition of Extracts}

Bioactive compounds considered to be responsible for pharmacological effects of willow were identified and quantified by HPLC analysis. The impact of different extraction conditions on chemical composition of Salix caprea L. bark and leaves extracts are shown in Tables 5 and 6.

Presence of active ingredients in the extracts was confirmed by comparing their retention time with the retention times of the standards, as well as comparing their UV/VIS spectra with the spectra of the standard signal.
Phenolic compounds identified in both Salix caprea L. bark and leaves extracts were gallic acid, chlorogenic acid and vanillic acid and the flavonoids identified were epicatechin, rutin, quercetin and naringenin. $p$-Hydroxybenzoic acid was found in bark extracts andferulic acid, trans-cinnamic acid and $p$-coumaric acid were identified in leaves extracts only. The most abundant polyphenols in bark extracts was rutin $(1.71 \mathrm{~g} / 100 \mathrm{~g} \mathrm{de})$. Also high amounts of chlorogenic acid (0.965 g/100 g de), $p$-hydroxybenzoic acid $(0.542 \mathrm{~g} / 100 \mathrm{~g}$ de $)$ and quercetin $(0.603 \mathrm{~g} / 100 \mathrm{~g}$ de) were detected in bark. Previous study of Salix aegyptiaca indicate a similar polyphenolic profile, where rutin was one of the predominant flavonols in ethanolic bark extract. ${ }^{33}$ Other published reports indicate that epicatechin is one of the most dominant flavonoids in willow bark extracted with polar solvents. ${ }^{34}$ In leaves extracts, rutin was also the most abundant polyphenol $(0.968 \mathrm{~g} / 100 \mathrm{~g}$ de), followed by naringenin $(0.434$ $\mathrm{g} / 100 \mathrm{~g} \mathrm{de})$ and quercetin $(0.226 \mathrm{~g} / 100 \mathrm{~g}$ de). Our results are in accordance with earlier published studies on polyphenol content in leaves of six different Salix species, which revealed that quercetin was one of the major flavonols. $^{35}$

Table 4. Total flavonoids content of S. caprea leaves and bark extracts [mg of quercetin equivalents per g of dried extract]

\begin{tabular}{|c|c|c|c|c|c|c|}
\hline Drug & $\begin{array}{l}\text { Extraction } \\
\text { time }\end{array}$ & 30\% EtOH & $40 \% \mathrm{EtOH}$ & $\begin{array}{c}\text { Extraction type } \\
50 \% \text { EtOH }\end{array}$ & $60 \% \mathrm{EtOH}$ & 70\% EtOH \\
\hline Leaves & $\begin{array}{c}30 \mathrm{~min} \\
24 \mathrm{~h} \\
48 \mathrm{~h} \\
72 \mathrm{~h}\end{array}$ & $\begin{array}{l}4.07 \pm 0.09 \mathrm{ad}^{\mathrm{a}} \\
1.03 \pm 0.08 \mathrm{ad}^{\mathrm{b}} \\
0.91 \pm 0.04 \mathrm{ad}^{\mathrm{b}} \\
1.28 \pm 0.02 \mathrm{ad}^{\mathrm{c}}\end{array}$ & $\begin{array}{l}1.99 \pm 0.04 \mathrm{abd}^{\mathrm{a}} \\
1.72 \pm 0.04 \mathrm{abd}^{\mathrm{b}} \\
1.30 \pm 0.03 \mathrm{abd}^{\mathrm{c}} \\
7.01 \pm 0.03 \mathrm{abd}^{\mathrm{d}}\end{array}$ & $\begin{array}{l}2.93 \pm 0.03 \mathrm{a}^{\mathrm{a}} \\
2.57 \pm 0.03 \mathrm{a}^{\mathrm{b}} \\
2.09 \pm 0.02 \mathrm{a}^{\mathrm{c}} \\
1.76 \pm 0.03 \mathrm{a}^{\mathrm{d}}\end{array}$ & $\begin{array}{l}4.69 \pm 0.03 \mathrm{bd}^{\mathrm{a}} \\
7.50 \pm 0.04 \mathrm{bd}^{\mathrm{b}} \\
8.14 \pm 0.05 \mathrm{bd}^{\mathrm{c}} \\
5.76 \pm 0.04 \mathrm{bd}^{\mathrm{d}}\end{array}$ & $\begin{array}{l}16.92 \pm 0.01{ }^{c}{ }^{a} \\
15.10 \pm 0.07{ }^{c} \\
15.21 \pm 0.04{ }_{c}^{b c} \\
14.86 \pm 0.02{ }_{c}{ }^{b d}\end{array}$ \\
\hline Bark & $\begin{array}{c}30 \mathrm{~min} \\
24 \mathrm{~h} \\
48 \mathrm{~h} \\
72 \mathrm{~h}\end{array}$ & $\begin{array}{l}4.45 \pm 0.03 \mathrm{a}^{\mathrm{a}} \\
4.08 \pm 0.03 \mathrm{a}^{\mathrm{b}} \\
3.91 \pm 0.00 \mathrm{a}^{\mathrm{b}} \\
3.75 \pm 0.01 \mathrm{a}^{\mathrm{c}}\end{array}$ & $\begin{array}{l}5.69 \pm 0.03 \mathrm{~b}^{\mathrm{a}} \\
5.84 \pm 0.01 \mathrm{~b}^{\mathrm{b}} \\
5.71 \pm 0.00 \mathrm{~b}^{\mathrm{ac}} \\
5.76 \pm 0.06_{\mathrm{b}}{ }^{\mathrm{a}}\end{array}$ & $\begin{array}{l}5.38 \pm 0.011_{b}{ }^{a} \\
7.28 \pm 0.01 b_{b}^{b} \\
6.28 \pm 0.01 b^{c} \\
4.42 \pm 0.03 b_{b}\end{array}$ & $\begin{array}{r}7.16 \pm 0.06_{c^{a}}{ }^{a} \\
8.70 \pm 0.06_{c^{b}} \\
8.38 \pm 0.05_{c^{c}} \\
11.23 \pm 0.00_{c}{ }^{d}\end{array}$ & $\begin{array}{l}15.19 \pm 0.02 \mathrm{~d}^{\mathrm{a}} \\
15.65 \pm 0.05 \mathrm{~d}^{\mathrm{b}} \\
18.24 \pm 0.01 \mathrm{~d}^{\mathrm{c}} \\
17.95 \pm 0.06 \mathrm{~d}^{\mathrm{c}}\end{array}$ \\
\hline
\end{tabular}

Data are presented as mean value of triplicate measurements \pm standard deviation; Superscript letters within the same column indicate significant $(P<$ $0.05)$ differences of means within the extracting solvent; Subscript letters indicate significant $(P<0.05)$ differences of means between extraction types. 
Table 5. Chemical composition of Salix caprea leaves extracts

\begin{tabular}{|c|c|c|c|c|c|c|c|c|c|c|c|c|}
\hline $\begin{array}{l}\text { Extraction } \\
\text { type }\end{array}$ & \multicolumn{11}{|c|}{ [g/100 g drug] } & SA \\
\hline \multirow{4}{*}{$30 \% \mathrm{EtOH}$} & $30 \mathrm{~min}$ & n.d. & n.d. & n.d. & n.d. & 0.009 & 0.046 & 0.074 & n.d. & n.d. & 0.092 & n.d. \\
\hline & $24 \mathrm{~h}$ & n.d. & n.d. & n.d. & n.d & 0.014 & 0.047 & 0.077 & 0.035 & 0.0009 & 0.122 & \\
\hline & $48 \mathrm{~h}$ & n.d. & n.d. & 0.003 & n.d. & 0.009 & 0.057 & n.d. & 0.043 & 0.0011 & 0.204 & \\
\hline & $72 \mathrm{~h}$ & n.d. & 0.019 & 0.005 & 0.0004 & n.d. & 0.045 & 0.070 & 0.036 & 0.0011 & 0.091 & \\
\hline \multirow{4}{*}{$40 \% \mathrm{EtOH}$} & $30 \mathrm{~min}$ & n.d. & 0.030 & 0.001 & n.d. & n.d. & 0.072 & 0.100 & 0.048 & 0.0009 & 0.136 & \\
\hline & $24 \mathrm{~h}$ & 0.071 & n.d. & 0.003 & 0.003 & 0.012 & 0.044 & 0.073 & 0.034 & 0.0008 & 0.092 & \\
\hline & $48 \mathrm{~h}$ & n.d. & n.d. & 0.006 & 0.087 & 0.0008 & 0.052 & 0.072 & 0.044 & 0.005 & 0.160 & \\
\hline & $72 \mathrm{~h}$ & n.d. & n.d. & n.d. & n.d. & n.d. & 0.049 & n.d. & 0.048 & 0.002 & 0.302 & \\
\hline \multirow{4}{*}{$50 \% \mathrm{EtOH}$} & $30 \mathrm{~min}$ & n.d. & n.d. & 0.008 & 0.002 & 0.008 & 0.056 & 0.083 & 0.047 & 0.004 & 0.188 & \\
\hline & $24 \mathrm{~h}$ & 0.074 & 0.027 & n.d. & 0.013 & 0.011 & 0.058 & 0.084 & 0.052 & 0.007 & 0.131 & \\
\hline & $48 \mathrm{~h}$ & 0.068 & n.d. & n.d. & 0.007 & 0.007 & 0.057 & 0.075 & 0.069 & 0.026 & 0.141 & \\
\hline & $72 \mathrm{~h}$ & n.d. & n.d. & n.d. & n.d. & n.d. & 0.105 & n.d. & 0.066 & 0.006 & 0.330 & \\
\hline \multirow{4}{*}{$60 \% \mathrm{EtOH}$} & $30 \mathrm{~min}$ & 0.099 & n.d. & n.d. & 0.021 & n.d. & 0.099 & 0.095 & 0.073 & 0.009 & 0.330 & \\
\hline & $24 \mathrm{~h}$ & 0.077 & 0.100 & n.d. & 0.015 & 0.011 & 0.259 & n.d. & 0.060 & 0.023 & 0.113 & \\
\hline & $48 \mathrm{~h}$ & n.d. & n.d. & n.d. & n.d. & n.d. & 0.968 & n.d. & 0.067 & 0.035 & 0.156 & \\
\hline & $72 \mathrm{~h}$ & n.d. & n.d. & 0.017 & 0.009 & 0.007 & 0.054 & 0.076 & 0.068 & 0.043 & 0.136 & \\
\hline \multirow{4}{*}{$70 \%$ EtOH } & $30 \mathrm{~min}$ & 0.111 & 0.082 & 0.002 & 0.002 & 0.020 & 0.129 & n.d. & 0.185 & 0.075 & 0.319 & \\
\hline & $24 \mathrm{~h}$ & n.d. & n.d. & n.d. & 0.028 & 0.015 & 0.089 & n.d. & 0.087 & 0.033 & 0.146 & \\
\hline & $48 \mathrm{~h}$ & n.d. & n.d. & 0.013 & 0.015 & n.d. & 0.177 & n.d. & 0.226 & 0.090 & 0.434 & \\
\hline & $72 \mathrm{~h}$ & 0.060 & 0.028 & 0.0002 & 0.055 & n.d. & 0.116 & n.d. & 0.125 & 0.032 & 0.032 & \\
\hline
\end{tabular}

n.d. - not detected; GA - gallic acid; CHLA - chlorogenic acid; PHB - p-hydroxybenzoic acid; VA - vanillic acid; EPC - epicatechin; CA - p-coumaric acid; R - rutin; FA - ferulic acid Q - quercetin; NRG - naringenin; SA - salicin

Table 6. Chemical composition of Salix caprea bark extracts

\begin{tabular}{|c|c|c|c|c|c|c|c|c|c|c|}
\hline Extraction type & Time & GA & CHLA & PHB & $\begin{array}{c}\text { VA } \\
00 \mathrm{~g} \text { de] }\end{array}$ & EPC & $\mathbf{R}$ & $\mathbf{Q}$ & NRG & SA \\
\hline \multirow{4}{*}{$30 \% \mathrm{EtOH}$} & $30 \mathrm{~min}$ & n.d. & 0.004 & 0.020 & 0.008 & 0.0006 & 0.087 & 0.043 & n.d. & n.d. \\
\hline & $24 \mathrm{~h}$ & n.d. & 0.202 & n.d. & 0.027 & 0.093 & 0.329 & 0.091 & n.d. & n.d. \\
\hline & $48 \mathrm{~h}$ & n.d. & 0.019 & 0.0009 & 0.003 & 0.002 & 0.064 & 0.042 & n.d. & n.d. \\
\hline & $72 \mathrm{~h}$ & n.d. & 0.035 & 0.003 & 0.004 & 0.010 & 0.099 & 0.101 & 0.052 & n.d. \\
\hline \multirow{4}{*}{$40 \% \mathrm{EtOH}$} & $30 \mathrm{~min}$ & n.d. & 0.093 & 0.111 & 0.047 & 0.050 & 0.428 & 0.074 & 0.078 & 0.789 \\
\hline & $24 \mathrm{~h}$ & n.d. & 0.050 & 0.007 & 0.009 & 0.007 & 0.128 & 0.066 & 0.061 & 0.250 \\
\hline & $48 \mathrm{~h}$ & 0.032 & 0.10 & 0.078 & 0.070 & 0.134 & 0.341 & 0.138 & 0.055 & 0.273 \\
\hline & $72 \mathrm{~h}$ & 0.068 & 0.166 & 0.078 & 0.077 & 0.285 & 0.620 & 0.304 & 0.103 & 0.269 \\
\hline \multirow{4}{*}{$40 \% \mathrm{EtOH}$} & $30 \mathrm{~min}$ & 0.043 & 0.285 & 0.252 & 0.143 & 0.108 & 0.786 & 0.155 & 0.086 & 0.749 \\
\hline & $24 \mathrm{~h}$ & 0.035 & 0.092 & 0.074 & 0.005 & 0.039 & 0.243 & 0.106 & 0.076 & 0.638 \\
\hline & $48 \mathrm{~h}$ & 0.030 & 0.165 & 0.107 & 0.082 & 0.218 & 0.783 & 0.139 & 0.082 & 0.469 \\
\hline & $72 \mathrm{~h}$ & 0.057 & 0.536 & 0.307 & 0.302 & 0.699 & 1.470 & 0.429 & 0.153 & 0.530 \\
\hline \multirow{4}{*}{$60 \% \mathrm{EtOH}$} & $30 \mathrm{~min}$ & 0.032 & 0.244 & 0.293 & 0.117 & 0.17 & 1.135 & 0.168 & 0.072 & 0.615 \\
\hline & $24 \mathrm{~h}$ & 0.029 & 0.294 & 0.135 & 0.098 & 0.412 & 0.980 & 0.244 & 0.074 & 0.628 \\
\hline & $48 \mathrm{~h}$ & n.d. & 0.702 & 0.091 & 0.114 & 0.435 & 1.710 & 0.31 & 0.115 & 0.461 \\
\hline & $72 \mathrm{~h}$ & 0.054 & 0.965 & 0.332 & 0.232 & 0.697 & 1.442 & 0.344 & 0.127 & n.d. \\
\hline \multirow{4}{*}{$70 \% \mathrm{EtOH}$} & $30 \mathrm{~min}$ & 0.113 & 0.563 & 0.542 & 0.329 & 0.672 & 1.320 & 0.603 & 0.157 & 0.658 \\
\hline & $24 \mathrm{~h}$ & n.d. & 0.583 & 0.29 & 0.172 & 0.267 & 0.550 & 0.098 & 0.05 & 0.598 \\
\hline & $48 \mathrm{~h}$ & n.d. & 0.825 & 0.43 & 0.486 & 0.499 & 1.680 & 0.642 & 0.111 & 0.413 \\
\hline & $72 \mathrm{~h}$ & 0.093 & 0.655 & 0.34 & 0.209 & 0.649 & 1.630 & 0.532 & 0.130 & 0.604 \\
\hline
\end{tabular}


Gallic acid content varied from 0.029 to $0.113 \mathrm{~g} / 100$ $\mathrm{g}$ de and from 0.060 to $0.111 \mathrm{~g} / 100 \mathrm{~g}$ de in bark and leaves, respectively. The highest amount of gallic acid in leaves was found in $70 \%$ ethanolic extract. It was not detected in either bark or leaves extracts obtained by maceration with $30 \%$ ethanol, implying that this concentration of ethanol is not selective for gallic acid isolation. The amount of chlorogenic acid was in interval of $0.004-0.965 \mathrm{~g} / 100 \mathrm{~g}$ de and $0.019-0.100 \mathrm{~g} / 100 \mathrm{~g}$ de for bark and leaves, respectively. The highest quantity of chlorogenic acid in bark and leaves was obtained by maceration with $60 \%$ ethanol. Vanillic acid content was in interval of 0.003 to $0.486 \mathrm{~g} / 100 \mathrm{~g}$ de in bark and 0.0002 to $0.017 \mathrm{~g} / 100 \mathrm{~g}$ de in leaves. The highest amount of vanillic acid in bark was obtained by maceration with $70 \%$ ethanol for 48 hours, and in leaves by maceration with $60 \%$ ethanol during $72 \mathrm{~h}$ of extraction. The amount of epicatechin was in interval of $0.0006-0.699$ $\mathrm{g} / 100 \mathrm{~g}$ de and $0.0004-0.087 \mathrm{~g} / 100 \mathrm{~g}$ de for bark and leaves, respectively. The highest quantity of epicatechin in bark was obtained by $50 \%$ ethanol and in leaves $40 \%$ ethanol is found to be most effective extraction solvent. The highest content of rutin in both, bark and leaves, was found in $60 \%$ ethanolic extract obtained after 48 hours of maceration. Quercetin was obtained in highest amount in both, bark and leaves, by maceration with $70 \%$ ethanol for 48 hours. The amount of naringenin in bark was in interval of 0.050 to $0.157 \mathrm{~g} / 100 \mathrm{~g}$ de, which is similar to results obtained for Salix caprea wood and knots $(0.5-1.5 \mathrm{mg} / \mathrm{g})$ published earlier. ${ }^{20}$ Even higher amounts of naringenin were found in leaves extracts $(0.091-0.330 \mathrm{~g} / 100 \mathrm{~g}$ de). $P$-hydroxybenzoic acid was detected in bark only $(0.0009-0.542 \mathrm{~g} / 100 \mathrm{~g}$ de), with the highest amount in 70\% ethanolic extract obtained after 48 hours of maceration. Ferulic acid was found in leaves only $(0.07-0.100 \mathrm{~g} / 100 \mathrm{~g}$ de), with the highest amount in $40 \%$ ethanolic extract. Trans-cinnamic acid $(0.0008-0.09 \mathrm{~g} / 100 \mathrm{~g} \mathrm{de})$ and $p$-coumaric acid (0.0008$0.020 \mathrm{~g} / 100 \mathrm{~g}$ de) were found in low amounts in leaves only. Salicin was detected in bark extracts only. Its content ranged from 0.250 to $0.789 \mathrm{~g} / 100 \mathrm{~g}$ de. The highest amount of salicin was obtained in $40 \%$ ethanolic extract after 30 min of maceration, while in $30 \%$ ethanolic extracts it was not detected at all. Salicin content in our study is higher compared to the amount of salicin obtained in a similar research, where Salix caprea bark and leaves were extracted with methanol. ${ }^{25}$ However, in the mentioned study, salicin was detected also in leaves extracts, which was not the case in our research. These quantitative variations within the same species could reflect the influence of environmental and also genetic factors.

Correlation between antioxidant activity and the determined compounds in Salix caprea leaves and bark extracts was tested. There is statistically no significant correlation between antioxidant activity and any of the determined compounds in leaves extracts. In case of bark, statistically significant moderate negative correlation between antioxidant activity and rutin $(\mathrm{R}=-0.485$, level of significance $p<0.05)$, naringenin $(R=-0.474$, level of significance $\mathrm{p}<0.05)$ and salicin $(\mathrm{R}=-0.541$, level of significance $p<0.05)$ was observed, suggesting that these compounds might contribute to the antioxidant activity of Salix caprea bark extracts.

\section{3. Molecular Docking}

Molecular docking, as effective tool used to investigate the active site of a protein and to elucidate the interactions between ligands and the biological molecule, was applied in our research. One of the most important compound of willow bark, salicin, was selected to study its binding affinity and interactions to COX-1 and COX-2 enzymes. Binding energies and inhibition constants for the studied ligand and control inhibitor acetylsalicylic acid are listed in Table 7.

The results presented in Table 7 showed salicin to have similar affinity toward COX-1 and COX-2 enzymes. Also, in comparison with acetylsalicylic acid, salicin showed similar affinity toward COX-2, but lower toward COX-1. Acetylsalicylic acid, also known as aspirin is currently one of the most widely used drugs worldwide owing to its analgesic, antipyretic, anti-inflammatory and cardioprotective effects. ${ }^{36}$ Aspirin irreversibly inhibits both isozymes of COX, but with a greater potency for COX-1, ${ }^{36}$ which was demonstrated by our docking study as well. COX-1 is constitutively expressed in blood platelets and most tissues, particularly gastric mucosal cells, whereas COX-2 is an inducible form expressed during inflammation. Therapeutic effects of acetylsalicylic acid are achieved by COX-2 inhibition, while inhibition of COX-1 is responsible for the side effects. ${ }^{36}$ The risk of adverse effects, especially gastrointestinal mucosa damage, limits the benefit of aspirin use. ${ }^{37}$ Lower affinity of salicin toward COX-1 might partially explain why willow bark extract does not damage the gastrointestinal mucosa in contrast to aspirin. ${ }^{38}$ Interactions of salicin with amino acid residues at

Table 7. Binding energies and inhibition constants

\begin{tabular}{lcccr}
\hline \multirow{2}{*}{ Compound } & \multicolumn{2}{c}{ COX-1 } & \multicolumn{2}{c}{ COX-2 } \\
& Binding energy & \multicolumn{2}{c}{ Binding energy [ } \\
& {$[\mathbf{k c a l} / \mathbf{m o l}]$} & $\mathbf{K}_{\mathbf{i}}[\boldsymbol{\mu M}]$ & $\mathbf{k c a l} / \mathbf{m o l}]$ & $\mathbf{K}_{\mathbf{i}}[\boldsymbol{\mu M}]$ \\
\hline Salicin & -5.70 & 66.54 & -5.86 & 50.95 \\
Acetylsalicylic acid & -6.25 & 26.1 & -5.69 & 67.66 \\
\hline
\end{tabular}

Gligorić et al.: Methodological Aspects of Extraction, ... 
a)

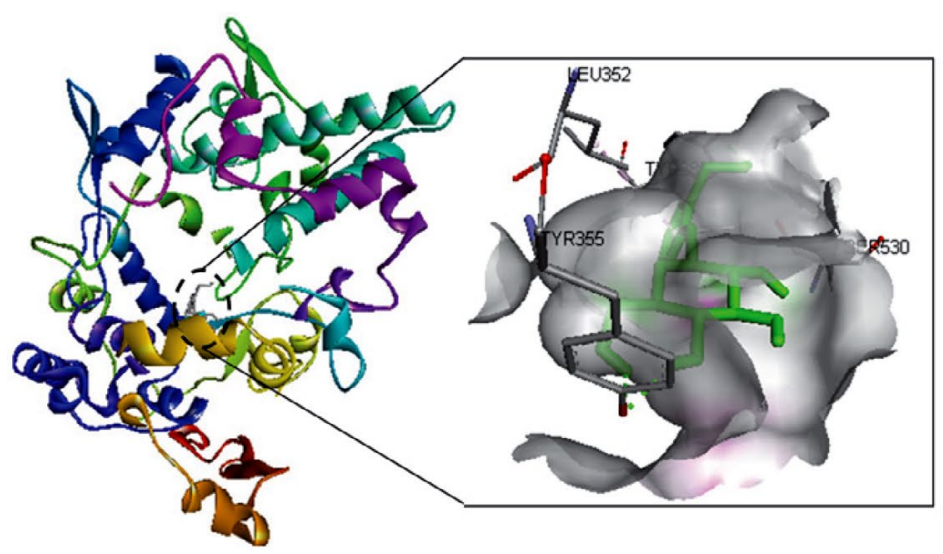

Figure 1. Active site of the COX-1 enzyme with salicin (A) 3D view; B) 2D view) b)

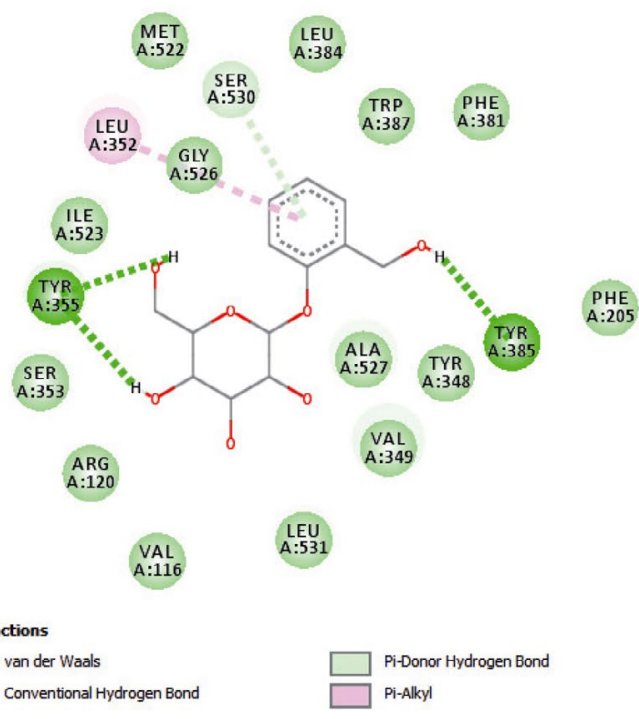

a)

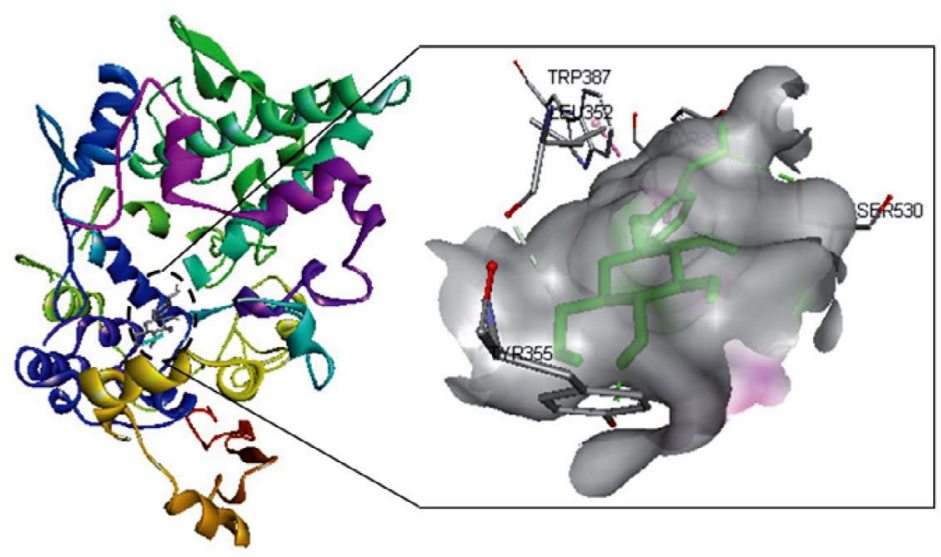

b)



Figure 2. Active site of the COX-2 enzyme with salicin (A) 3D view; B) 2D view)

the active site of COX-1 and COX-2 are shown in Figures 1 and 2 .

Salicin was involved in hydrogen bonding with amino acid residues of the active site of COX-1 Tyr 355, Tyr 385 and Ser 530. Other important active site amino acid residues Arg 120, Val 349, Ser 353, Leu 384, Trp 387, Met 522, Ile 523, Gly 526 and Ala 527 form van der Waals interactions with salicin. These amino acid residues have also been reported for curcumin analogues having strong interactions with COX-1. ${ }^{39}$ Salicin showed hydrogen bonding with Leu 352, Tyr 355, Tyr 385 and Ser 530, which are relevant amino acid residues of the active site of COX-2. Previous studies revealed that Ser-530 and Tyr-385 are important for the inhibition of COX-2. ${ }^{3}$ Salicin exhibited hydrophobic interactions with important amino acid resi- dues of the active site, namely Arg 120, Tyr 348, Val 349, Leu 352, Ser 353, Leu359, Trp 387, Phe 518, Met 522, Val 523, Gly 526 and Ala 527. Interactions with most of these residues have also been reported for compounds showing strong inhibition of COX-2 and correspond to the active binding site of non-steroidal anti-inflammatory drugs. ${ }^{39-41}$

\section{Conclusion}

Extraction technique showed great impact on yield, antioxidant activity and the amount of active compounds of Salix caprea bark and leaves. 70\% ethanolic extracts exhibited highest antioxidant activity. Although willow extracts have been traditionally used as anti-inflammatory agents for their salicin content, Salix caprea bark and leaves contain significant amounts of other phenolic com- 
pounds, especially epicatechin, rutin, quercetin, chlorogenic acid and gallic acid, which act as potent antioxidants, and therefore can contribute to the therapeutic effects of this species. Also, the results obtained in our study showed that Salix caprea leaves, as well as bark could be used as a rich natural source of bioactive components and have potential in the pharmaceutical industry for extraction of phenolic antioxidants. Salicin was found in bark extracts only and molecular docking study was applied for evaluation of interactions and binding affinity between salicin and the enzymes COX-1 and COX-2. The results showed that salicin exhibited a number of strong hydrogen bonds and hydrophobic interactions with significant amino acid residues of active sites of COX-2 which could explain major anti-inflammatory potency of this compound.

\section{Abbreviations}

Ala, alanine; Arg, arginine; COX, cyclooxygenase; d.e., dried extract; $\mathrm{DPPH}^{\circ}$, 2,2-diphenyl-1-picrylhydrazyl radical; GAE, gallic acid equivalents; Gly, glycine; Ile, isoleucine; Leu, leucine; Met, methionine; ${ }^{\circ} \mathrm{OH}$, hydroxyl radical; Phe, phenylalanine; Ser, serine; Trp, tryptophan; Tyr, tyrosine; $\mathrm{QE}$, quercetin equivalents.

\section{Acknowledgement}

This study was supported by the Ministry of Education, Science and Technological Development of the Republic of Serbia, projects no. 172021 and III 46009.

\section{References}

1. B. Schmidt, I. Kötter, L. Heide, Eur. J. Clin. Pharmacol. 2001, 57, 387-391. DOI:10.1007/s002280100325

2. L. Poblocka-Olech, A. M. van Nederkassel, Y. Vander Heyden, M. Krauze-Baranowska, D. Głód, T. Bascek, J. Sep. Sci. 2007, 30, 2958-2966. DOI:10.1002/jssc. 200700137

3. M. Shara, S. J. Stohs, Phytother. Res. 2015, 29, 1112-1116. DOI:10.1002/ptr.5377

4. S. Agnolet, S. Wiese, R. Verpoorte, D. Staerk, J. Chromatogr. A. 2012, 1262, 130-137. DOI:10.1016/j.chroma.2012.09.013

5. A. Durak, U. Gawlik-Dziki, D. Sugier, J. Funct. Foods, 2015, 18, 1106-1116. DOI:10.1016/j.jff.2014.06.012

6. L. Pobłocka-Olech, M. Krauze-Baranowska, D. Głód, A. Kawiak, E. Łojkowska, Phytochem. Anal. 2010, 21, 463-469. DOI:10.1002/pca.1220

7. A. Nahrstedt, M. Schmidt, R. Jaggi, J. Metz, M. T. Khayyal, Wochenschr. 2007, 157, 348-351.

DOI:10.1007/s10354-007-0437-3

8. B. Uehleke, J. Müller, R. Stange, O. Kelber, J. Melzer, Phytomedicine, 2013, 20, 980-984.

DOI:10.1016/j.phymed.2013.03.023
9. Lj. Babincev, Lj. Rajaković, M. Budimir, A. Perić-Grujić, D. Sejmanović, Chem. Ind. 2011, 65, 397-401.

DOI:10.2298/HEMIND110222025B

10. A. Ahmed, W. A. Shah, S. Akbar, M. Younis, D. Kumar, Int. J. Res. Phytochem. Pharmacol. 2011, 1, 17-20.

11. S. Sultana, M. Saleem, Ethnopharmacol. 2004, 91, 267-276. DOI:10.1016/j.jep.2003.12.028

12. M. Anđelković, A. Milenković-Anđelković, B. Radovanović, A. Radovanović, Acta Chim. Slov. 2014, 61, 858-865.

13. S. Grujić, A. Džamić, V. Mitić, V. Stankov-Jovanović, P. Marin, G. Stojanović, Chem. Ind. 2017, 71, 361-370.

DOI:10.2298/HEMIND160518047G

14. B. Teofilović, N. Grujić-Letić, S. Kovačević, S, Podunavac-Kuzmanović, S. Gadžurić, Chem. Ind. Chem. Eng. Q. 2017, DOI:10.2298/CICEQ170217035T

15. B. Teofilović, N. Grujić-Letić, S. Goločorbin-Kon, S. Stojanović, Gyongyi Vastag, S. Gadžurić, Ind. Crops. Prod. 2017, 100, 176-182. DOI:10.1016/j.indcrop.2017.02.039

16. N. Grujić-Letić, Ž. Lepojević, B. Srđenović, J. Vladić, J. Suđi, Molecules, 2012, 17, 2518-2528.

DOI:10.3390/molecules 17032518

17. A. Bucić-Kojić, M. Planinić, S. Tomas, S. Jokić, I. Mujić, M. Bilić, Polish J. Food Nutr. Sci. 2011, 61, 195-199.

DOI:10.2478/v10222-011-0021-9

18. M. Alothman, R. Bhat, A.A. Karim, Food Chem. 2009, 115, 785-788. DOI:10.1016/j.foodchem.2008.12.005

19. M. P. Kähkönen, A. I. Hopia, H. J. Vuorela, J. P. Rauha, K. Pihlaja, T. S. Kujala, J. Agric. Food Chem. 1999, 47, 3954-3962. DOI:10.1021/jf9901461

20. S. P. Pohjamo, J. E. Hemming, S. M. Willför, M. H. T. Reunanen, B. R. Holmbom, Phytochemistry, 2003, 63, 165-169. DOI:10.1016/S0031-9422(03)00050-5

21. M. Amaravani, N. Prasad, V. Ramakrishna, Springerplus, 2012, 1, 58. DOI:10.1186/2193-1801-1-58

22. P. Srivastava, V. Singh, B. Singh, G. Srivastava, B. Misra, V. Tripathi, J. Proteomics Bioinform. 2013, 6, 109-124.

23. EMA/HMPC. http://www.ema.europa.eu/ema/index.jsp?cur l=pages/home/Home_Page.jsp\&mid=

24. A. Ziakova, E. Bransteterova, J. Liq. Chromatogr. Relat. Technol. 2003, 26, 443-453. DOI:10.1081/JLC-120017181

25. A. Guvenc, O. Arihan, M. L. Altun, E. Dinc, D. Baleanu, D, Rev. Chim, 2007, 58, 8-12.

26. A. Cvetanović, J. Švarc-Gajić, P. Mašković, S. Savić, Lj. Nikolić, Ind. Crop Prod. 2015, 65, 582-591. DOI:10.1016/j.indcrop.2014.09.044

27. M. S. Stankovic, M. Topuzovic, S. Solujic, V. Mihailovic, J. Med. Plant Res. 2010, 4, 2092-2098.

28. A. Djeridane, M. Yousfi, B. Nadjemi, D. Boutassouna, P. Stocker, N. Vidal, Food Chem. 2006, 97, 654-660. DOI:10.1016/j.foodchem.2005.04.028

29. D. Picot, P. J. Loll, R. M. Garavito, Nature, 1994, 367, 243-249. DOI: $10.1038 / 367243 \mathrm{a} 0$

30. R. G. Kurumbail, A. M. Stevens, J. K. Gierse, J. J. McDonald, R. A. Stegeman, J. Y. Pak, Nature, 1996, 384, 644-648. DOI: $10.1038 / 384644 \mathrm{a} 0$

31. G. M. Morris, R. Huey, W. Lindstrom, M. F. Sanner, R. K. 
Belew, D. S. Goodsell, J. Comput. Chem. 2009, 30, 2785-2791. DOI: $10.1002 /$ jcc. 21256

32. M. Naczk, F. Shahidi, J. Pharm. Biomed. Anal. 2006, 41, 15231542. DOI:10.1016/j.jpba.2006.04.002

33. S. Enayat, S. Banerjee, Food Chem. 2009, 116, 23-28. DOI:10.1016/j.foodchem.2009.01.092

34. G. Jürgenliemk, F. Petereit, A. Nahrstedt, Pharmazie, 2007, $62,231-234$

35. T. Nyman, R. Julkunen-Tiitto, Phytochemistry, 2005, 66, 2836-2843. DOI:10.1016/j.phytochem.2005.09.040

36. M. N. Marjan, M. T. Hamzek, E. Rahman, V. Sadeq, Comput. Biol. Chem., 2014, 51, 57-62.

DOI:10.1016/j.compbiolchem.2014.05.002
37. A. Negovan, M. Iancu, V. Moldovan, S. Voidazan, S. Bataga, M. Pantea, K. Sarkany, C. Tatar, S. Mocan, C. Banescu, Gastroenterol. Res. Pract., 2016, 2016, 7230626.

DOI:10.1155/2016/7230626

38. J. Vlachojannis, F. Magora, S. Chrubasik, Phytother. Res. 2011, 25, 1102-1104. DOI:10.1002/ptr.3386

39. C. Selvam, S. M. Jachak, R. Thilagavathi, A. K. Chakraborti, Bioorg. Med. Chem. Lett. 2005, 15, 1793-1797.

DOI:10.1016/j.bmcl.2005.02.039

40. K. C. Duggan, M. J. Walters, J. Musee, J. M. Harp, J. R. Kiefer, J. A. Oates, J. Biol. Chem. 2010, 285, 34950-34959. DOI:10.1074/jbc.M110.162982

41. K. E. Furse, D. A. Pratt, C. Schneider, A. R. Brash, N. A. Porter, T. P. Lybrand, Biochemistry, 2006, 45, 3206-3218. DOI:10.1021/bi052338h

\section{Povzetek}

Vsebino dvanajstih izbranih bioaktivnih snovi in antioksidativni potencial ekstraktov Salix caprea L. smo primerjali $\mathrm{v}$ dveh vegetativnih organih (lubje in listi) ter glede na različne mešanice etanol/voda, ki se uporabljajo za ekstrakcijo (30-70 \% vodni, etanol) in ekstrakcijski čas (30 min; 24, 48 in 72 h). Ekstrakte smo opredelili s tekočinsko kromatografijo pod visokim pritiskom (HPLC), skupni fenoli in flavonoidi pa so bili določeni spektrofotometrično. Vsi sekundarni presnovki, ki so bili opredeljeni v ekstraktih Salix caprea L. (galna, klorogena in vanilinska kislina, epikatehin, rutin, kvercetin in naringenin), so se nabrali v lubju. Salicin in $p$-hidroksibenzojska kislina sta bila odkrita le v lubju in ferulinski, trans-cimetni in $p$-kumarni kislini le v ekstraktih listov. Rutin je bil najbolj obilna bioaktivna spojina tako v lubju ( $1,71 \mathrm{~g} / 100 \mathrm{~g}$ de), kot tudi v listih ekstrakta (0,434 g / $100 \mathrm{~g}$ de). Ekstrakt lubja $\mathrm{z}$ najvišjo vsebnostjo bioaktivnih snovi je bil pridobljen s $70 \%$ vodnega etanola kot najprimernejše topilo v času ekstrakcije $48 \mathrm{~h}$. Molekularno povezovanje je pokazalo, da ima salicin podobne afinitete do COX-2 kot acetilsalicilna kislina, proti COX-1 pa nižje.

Except when otherwise noted, articles in this journal are published under the terms and conditions of the Creative Commons Attribution 4.0 International License 